\title{
An integrated ANP-ELECTRE III decision model applied to eco-friendly car selection
}

\author{
Ahmad Mumani* and Ghazi M. Magableh \\ Industrial Engineering Department, Yarmouk University, Irbid, Jordan. \\ *Corresponding Author: Ahmad.Mumani@yu.edu.jo \\ Submitted :29/07/2020 \\ Revised :25/05/2021 \\ Accepted :05/06/2021
}

\begin{abstract}
The number of green energy options in different fields is growing because of the need for reducing energy consumption and eliminating gas emission. One of these options is the use of eco-friendly cars produced by various manufacturers. Given the many available options and conflicting evaluation criteria, evaluation of such options becomes complex, and different multicriteria decision-making (MCDM) approaches have been used to select the most suitable car in terms of eco-friendly car selection. Previous research has been somewhat limited with respect to consideration of interdependencies between evaluation criteria and multilevels of preference. This paper proposes a new integrated MCDM approach with the capability for considering interdependent criteria for ecofriendly car evaluation and different levels of preference. An analytic network process (ANP) will be used to evaluate the levels of importance of interdependent criteria, and ELECTRE III will be modeled to include thresholds of preference. The introduced model, based on twenty-eight evaluation criteria, was demonstrated in a case study dealing with five alternative electric and hybrid cars. The results from this model were compared to a traditional decision-making method, and better results were obtained from the model. The model can help users make proper decisions regarding their future car options in a comprehensive manner. Sensitivity analysis showed the robustness of the model under different setups.
\end{abstract}

Keywords: ANP; ELECTRE III; Green cars; MCDM; Selection.

\section{INTRODUCTION}

Eco-friendly cars have recently come into wide use and have received great acceptance from a variety of cultures and governments (Paulino Mendoza, 2018). An intention to buy this sort of cars may differ from country to country and customer to customer (Yim \& Chong, 2018), but the adoption of such cars may generally be explained by their capability for saving energy and significantly reduce gas emissions (Chowdhury, Salam, \& Tay, 2016),(Sultana, Khairuddin, Rasheed, Qazi, \& Mokhtar, 2018) and (Rihab, Naourez, Mohamed, \& Rafik, 2021). The greater acceptance of such cars also comes in response to increased costs of regular fuel sources, especially in energy-poor countries. Other causes can be related to environmental and political issues, especially in industrially based countries. Many companies have begun producing electric and hybrid versions of their brands with different styles and capabilities, with the result that a variety of cars of this kind, with a wide range of technical specifications and prices, are now available to users in different countries. Rooted in the fact that preferences may 
differ widely with respect to basic needs, characteristics, and perceptions, a user should choose a car which fulfills his/her requirements and preferences. Accordingly, technical specifications, preferences, and financial aspects should all be considered when selecting an eco-friendly car.

The process of selecting an option can be performed using simple ranking methods when a simple selection choice is encountered, but systematic decision-making approaches are needed for dealing with complicated problems. In the context of eco-friendly car selection, given potential interdependencies among performance measures and uncertainties related to evaluation of alternatives, a systematic decision-making approach is required, so the decision-making process is likely to be even more complicated. Many decision-making methods have been applied to the selection of suitable cars with a particular focus on eco-friendly cars. However, the interdependencies among performance measures have often been only superficially considered in eco-friendly car selection, minimizing their importance in real case situations. In addition, little effort has been directed toward handling the uncertainties associated with eco-friendly car evaluation. Accordingly, there is a need to introduce a model, which is easily understood with capabilities to consider the complexities associated with interdependent selection criteria and uncertainties.

This paper seeks to introduce a realistic decision-making framework to aid in making good decisions regarding eco-friendly cars. The framework is composed of two integrated main stages; an analytic network process (ANP) method, and Elimination and Choice Expressing Reality (ELECTRE) III. The first stage will be structured to allow consideration of interdependencies between performance measures and provide limiting priorities for them. These weights of importance will then be used by ELECTRE III to perform consecutive outranking stages that seek to rank alternative cars based on specified preference thresholds.

This paper is organized as follows. Section 2 will provide a background of related work and previously used decision-making methods. Section 3 describes the methodology used and demonstrates its use in a real case study. Discussion, conclusions, and future work will be presented in Sections 4 and 5.

\section{BACKGROUND}

This section introduces previous work related to car selection and presents the decision-making method and evaluation measures used. ANP and ELECTRE III methods will also be briefly described.

\subsection{Related Work}

Modern lifestyles necessitate the use of cars and people have naturally become increasingly dependent on them. Car aesthetics also play a major role in framing consumers' perceptions, as stated by Ranscombe et al. (2011) who conducted a web-based study to evaluate preferences with respect to aesthetic features of cars and their influence on consumer perceptions. A study conducted on undergraduate students showed that cultural factors in developing countries can affect needs for new car possession (Belgiawan, Schmöcker, \& Fujii, 2013). On the other hand, considerable effort has been directed toward reducing the effects of an increase in the number of cars. For example, Ishak, Malingam, and Mansor (2016) proposed a Fuzzy-VIKOR method to aid in selection of a proper natural material used in a car's front hood to reduce car weight, improve fuel efficiency, and reduce emissions.

The problem of car selection has attracted researchers from the automobile industry, marketing, and decisionmaking fields. Previous research has focused on vehicle, material-handling equipment, and car selection based on a combination of performance measures and user perceptions. An integrated decision model was introduced based on Fuzzy set theory and TOPSIS and applied to the problem of crane selection (Amir Mohamadghasemi, Hadi- 
Vencheh, \& Hosseinzadeh Lotfi, 2020). MCDM framework was also developed by integrating fuzzy set theory and ELECTRE III; the resulted framework was applied to the material handling equipment evaluation and selection (A. Mohamadghasemi, Hadi-Vencheh, Lotfi, \& Khalilzadeh, 2020). To enhance understanding of user preferences with respect to luxury cars, an AHP model embodying various evaluation criteria was configured. The criteria in that model were weighted using AHP to allow comparisons between alternative cars (Apak, Göğüş, \& Karakadılar, 2012). In addition, Chand and Avikal (2016) introduced an AHP model for selecting the most suitable hatchback car from the Indian market. Sri Yogi (2018) used AHP and Technique for Order Preference by Similarity to Ideal Solution (TOPSIS) to improve understanding of costumer intention with respect to purchasing a two-wheeler India automobile. Singh, Singh, and Sandhu (2018) also introduced a decision-making framework for scooter selection based on a combined TOPSIS-AHP model structured from various evaluation criteria, and Biswas and Saha (2019) introduced a Fuzzy-AHP Based model integrated with a new MCDM method for selecting scooters. The results of that model were compared to other MCDM methods, with model attaining greater simplicity.

As another example, Yıldız and Ergül (2014) introduced a Fuzzy-TOPSIS decision-making framework for automobile selection, with Fuzzy AHP also utilized to structure the problem of car selection and determine relative weights of importance of the evaluation criteria. Subsequently, hierarchalgray relation analysis (GRA) and the Preference Ranking Organization Method for Enrichment Evaluation (PROMETHEE) were used to rank car alternatives (Sakthivel et al., 2013). Yousefi and Hadi-Vencheh (2010) combined scores of AHP and TOPSIS to rank aspects of automobiles to help Iranian automobile industries further understand consumer needs, with the scores validated using a data-envelopment analysis technique. The results demonstrated the superiority of the proposed model over individual AHP and TOPSIS models. Criteria for selecting sport-utility vehicles were examined using AHP with results showing the importance of safety, comfort, and quality to SUV users ((Tumuju, Lapian, \& Tumbuan, 2017) and ( Mangindaan,Saerang, \& Tumiwa 2017)). Criteria for selecting off-road double cabins in terms of their importance were also determined using AHP. Singh and Avikal (2019) also introduced an integrated MCDM model composed of two main stages of weight determination criteria and subciteria and ranking alternatives. A fuzzy-AHP model was built to determine the relative weights of importance, while a TOPSIS-based model was built to rank car alternatives.

An AHP-based model was also proposed to help make car purchase decisions based on many criteria and subcriteria structured in a hierarchy, and the results of the model were validated with market-share information about three cars (Byun, 2001). Kele (2019) introduced a decision-making framework composed of integrated Entropy and ELECTRE III, with the Entropy method used to weight evaluation criteria importance after which ELECTRE III used these weights to proceed through its outranking stages to rank car alternative. To allow consideration of interdependencies between evaluation criteria, a fuzzy-ANP model with capabilities for dealing with interdepenedet linguistic decision criteria has been developed, with criteria and subcriteria arranged in clusters, forming a network of interdependent criteria (Yayla, A \& Yildiz, 2013).

Multiple linear regression has also been used to determine the main factors affecting consumer preferences in Chennai toward small cars, with consumer preferences shown to be affected by factors of value, need, comfort, efficiency, accessibility, and ambition. For each factor, subfactors were shown and examined (Anandh \& Sundar, 2014). To enhance understanding of the needs of car consumers in India, factors with potential influences on the preferences of baby boomers toward car brands were investigated through a questionnaire-based study (Davey \& Balakrishnan, Principal, 2017).

Advances in automotive technology and the increased consumption of fuel and associated emissions have motivated automobile manufacturers to produce eco-friendly cars, and the result has been plenty of available options with various specifications and prices for consumers in different countries, making the process of car selection a multicriteria decision-making (MCDM) problem. To systematically deal with this problem, researchers 
began to propose MCDM models for facilitating the selection process. For example, Hamurcu and Eren (2018) introduced an integrated MCDM model that used AHP, TOPSIS, and Goal programming for electric car selection. Another MCDM model was introduced for selecting hybrid cars with the capability to handle different categories of customers (Fenwick \& Daim, 2011). Prakash and Mohanty (2017) introduced an integrated DEA and MonteCarlo simulation framework for use in green car selection. In that framework, historical data were used to classify green cars based on their performance. An AHP model was structured to seek the understanding of intention toward using eco-friendly cars, considering both electric and hybrid car alternatives to demonstrate the model (Jamil \& Aminuddin, 2019). In addition, Tampatty, Kindangen, and Tumbuan (2017) conducted a study that used AHP to explore factors affecting the adoption of low-cost green cars in Indonesia, with results showing factors of safety, quality, and price to be of higher importance than other factors. To motivate usage of electric cars, Mendoza (2018) introduced an AHP model seeking to better understand user preferences and intentions to use electric cars. Shariff et al. (2019) also built a Fuzzy-AHP model for better recognizing uncertainties associated with user decisions and intentions to buy eco-friendly cars, and the results of the that model were confirmed using a simple AHP model.

An integrated model was also introduced to aid in selecting among electrical cars. In that model, values of performance measures of hybrid electrical cars were determined using an operating- window method, after which a TOPSIS model was built using these values to rank car alternatives (İç \& Şimşek, 2019). An entropy-based multiattributive border approximation area comparison (MABAC) based model was also introduced to select hybrid cars based on performance measures of interest. In that model, an entropy method was used to determine relative weights of importance of evaluation criteria, while MABAC was used to evaluate performances of alternatives (Biswas \& Das, 2018). Mohamadabadi, Tichkowsky, and Kumar (2009) also introduced an MCDM model based on PROMETHEE for selection among fuel-based cars, including a hybrid-car option. Fuzzy-AHP was also used in selecting the most appropriate technology for electric-car battery development (Lee, Chen, Chan, \& Hung, 2015). The integration between ANP and ELECTRE III has not been introduced in the previous literature within the context of car selection. Table 1 summarizes previous work related to car selection.

Table 1. Summary of relevant research.

\begin{tabular}{|c|c|l|l|}
\hline Reference & Method & Application & Evaluation Criteria \\
\hline $\begin{array}{c}\text { (Paulino, } \\
2018)\end{array}$ & AHP & Electric car selection & $\begin{array}{l}\text { Demographics, consumers' personality, performance, financial aspects, } \\
\text { and government policies. }\end{array}$ \\
\hline $\begin{array}{c}\text { (Ishak et al., } \\
2016)\end{array}$ & Fuzzy-VIKOR & $\begin{array}{l}\text { Select natural material } \\
\text { for car front }\end{array}$ & Weight, fuel efficiency, and emissions. \\
\hline $\begin{array}{c}\text { (Tampatty et } \\
\text { al., 2017) }\end{array}$ & AHP & $\begin{array}{l}\text { Adpotion of low cost } \\
\text { green cars }\end{array}$ & Safety, quality, price, interior, comfortability, and advertisement \\
\hline $\begin{array}{c}\text { (Prakash \& } \\
\text { Mhanty, 2017) }\end{array}$ & DEA-Monte-Carlo & Green cars evaluation \\
\hline $\begin{array}{c}\text { (Apak et al., } \\
2012)\end{array}$ & AHP & $\begin{array}{l}\text { Preferences toward } \\
\text { capacity, miles per gallon MPG, and torque }\end{array}$ \\
\hline $\begin{array}{c}\text { (Chand \& } \\
\text { Avikal, 2016) }\end{array}$ & AHP & $\begin{array}{l}\text { Selection of suitable } \\
\text { hatchback car }\end{array}$ & $\begin{array}{l}\text { Cost, Brand name, fuel efficiency, interior and exterior design, after } \\
\text { sale service, and maintenance cost }\end{array}$ \\
\hline
\end{tabular}




\begin{tabular}{|c|c|c|c|}
\hline $\begin{array}{l}\text { (Sri Yogi, } \\
\text { 2018) }\end{array}$ & AHP- TOPSIS & $\begin{array}{l}\text { Preferences toward two- } \\
\text { wheeler automobile }\end{array}$ & $\begin{array}{l}\text { Operational, performance, economics, brand, and maintenance beam } \\
\text { light, ability climb, ease of changing gear, vibration, fuel saving, spare } \\
\text { parts price, trade value, uniqueness, colour, accessories installation, } \\
\text { service time, and easy to service at any station. }\end{array}$ \\
\hline $\begin{array}{l}\text { (Singh et al., } \\
\text { 2018) }\end{array}$ & TOPSIS-AHP & Scooter selection & Safety, quality, cost, style, comforts, and after sale service. \\
\hline $\begin{array}{l}\text { (Biswas \& } \\
\text { Saha, 2019) }\end{array}$ & Fuzzy-AHP & Scooter selection & Mileage, Top speed, kerb weight, fuel tank capacity, and Price \\
\hline $\begin{array}{l}\text { ( Hamurcu, \& } \\
\text { Eren 2018) }\end{array}$ & $\begin{array}{l}\text { AHP, TOPSIS, } \\
\text { nad Goal } \\
\text { programming }\end{array}$ & Electric car selection & Economic, Political, Social, and Ecological \\
\hline $\begin{array}{l}\text { (Fenwick \& } \\
\text { Daim, 2011) }\end{array}$ & MCDM & Hybrid car selection & Seating capacity, Horsepower, mile per gallon, and base price \\
\hline $\begin{array}{c}\text { (Anandh \& } \\
\text { Sundar, 2014) }\end{array}$ & $\begin{array}{l}\text { Multiple linear } \\
\text { regression }\end{array}$ & $\begin{array}{l}\text { Preferences toward } \\
\text { small cars }\end{array}$ & $\begin{array}{l}\text { value, need, comfortability, efficiency, accessibility, and ambition, } \\
\text { Less emission, Prestige value, Safety, Entertainment } \\
\text { Superior quality, price, Compactness, design, Range of colors, Fashion, } \\
\text { fuel consumption, maintenance, After sales service, Availability of } \\
\text { spare parts, Availability of service center, Brand image, Family use, } \\
\text { and Attractiveness }\end{array}$ \\
\hline $\begin{array}{l}\text { (Yildız \& } \\
\text { Ergül, 2014) }\end{array}$ & Fuzzy-TOPSIS & $\begin{array}{l}\text { Automobile car } \\
\text { selection }\end{array}$ & $\begin{array}{l}\text { Engine power, fuel consumption, after sale servuce, cylindrical } \\
\text { volume, sale price, aisthetic, and comfort }\end{array}$ \\
\hline $\begin{array}{l}\text { (Sakthivel et al., } \\
\text { 2013) }\end{array}$ & $\begin{array}{l}\text { Fuzzy-AHP, } \\
\text { hierarchy grey } \\
\text { relation and } \\
\text { PROMETHEE }\end{array}$ & Car selection & $\begin{array}{l}\text { safety (Seat belt, Body alarm, ABS, airbag, impact), performance } \\
\text { (speed, tourque, braking, noise, and comfort), economics (price, resale, } \\
\text { fuel, and insurance), exterior (model, style, color, decoration, length, } \\
\text { and dealer), convenience (loading, inside width, visibility, and audio), } \\
\text { warranty (spare parts, service, repaire, and satisfacttion), and } \\
\text { emmision (NOx, CO, HC, and smoke) }\end{array}$ \\
\hline $\begin{array}{l}\text { (Yousefi \& } \\
\text { Hadi-Vencheh, } \\
\text { 2010) }\end{array}$ & $\begin{array}{l}\text { AHP, TOPSIS, } \\
\text { and Data } \\
\text { envelopment } \\
\text { analysis }\end{array}$ & $\begin{array}{l}\text { Consumers preference } \\
\text { toward automobile cars }\end{array}$ & $\begin{array}{l}\text { Technichal features (engine feature, safety, speed, and comfrtableness), } \\
\text { beuty (internal and external design, and color variaty), manufacturers } \\
\text { (country, company, and brand), tools avialability ( spare parts, } \\
\text { consumption tools), economical aspects ( price, fuel consumption, and } \\
\text { payment flexibility), and social aspects ( satisfaction, advertisement, } \\
\text { and social atmosphere). }\end{array}$ \\
\hline $\begin{array}{l}\text { (Gerald Fandy } \\
\quad \text { Tumuju, } \\
\text { S.L.H.V.Joyce } \\
\text { Lapian, 2017) }\end{array}$ & AHP & $\begin{array}{l}\text { Sport utility veichle } \\
\text { selection }\end{array}$ & Safety, comfortability, quality price, interior, and advertising \\
\hline $\begin{array}{l}\text { (Mangindaan, } \\
\text { Saerang, \& } \\
\text { Tumiwa 2017) }\end{array}$ & AHP & $\begin{array}{l}\text { Selection of off road } \\
\text { douple cabins car }\end{array}$ & Product quality, price, interior, and comfort \\
\hline $\begin{array}{c}\text { (Singh, \& } \\
\text { Avikal2019) }\end{array}$ & $\begin{array}{l}\text { Fuzzy-AHP and } \\
\text { TOPSIS }\end{array}$ & Selection of Sedan Car & $\begin{array}{l}\text { Criteria of Economy, Performance, After sale service, Safety, and } \\
\text { Comfort were used with their subcriteria to evaluate alternative cars. }\end{array}$ \\
\hline
\end{tabular}




\begin{tabular}{|c|c|c|c|}
\hline (Byun, 2001) & AHP & Car selection & $\begin{array}{l}\text { Exterior ( model, style, length, decoration, color, and instrument } \\
\text { cluster), convenience ( inside width, loading, operating, fitting, and } \\
\text { audio system), performance ( tourque, speed, fuel tank, braking, noise, } \\
\text { and comfort), safety ( trunk, Seat belt, Body alarm, ABS, airbag, } \\
\text { and impact ), economic ( price, resale, fuel, insurance), dealer, and } \\
\text { warranty ( spare parts, service station, repaire time, and satisfacttion) }\end{array}$ \\
\hline $\begin{array}{l}\text { (Jamil \& } \\
\text { Aminuddin, } \\
\text { 2019) }\end{array}$ & AHP & $\begin{array}{l}\text { Eco-friendly cars } \\
\text { selection }\end{array}$ & $\begin{array}{l}\text { Service, price, fule economy, safety, design, peformance, and } \\
\text { emmision. }\end{array}$ \\
\hline (Kele, 2019) & ELECTRE III & Car selection & Price and technical specifications \\
\hline $\begin{array}{c}\text { (Yayla, A \& } \\
\text { Yildiz, 2013) }\end{array}$ & Fuzzy-ANP & Car selection & $\begin{array}{l}\text { Performaance ( engine cylender, engine power, acceleration), safety } \\
\text { (road holding, material used, and safety system), economy ( sale price, } \\
\text { fuel consumption, taxes, and maintenance cost), comfort ( sielent, } \\
\text { width, and vibration), and after sale services ( spare part supplies, } \\
\text { insurance service, and technical support) }\end{array}$ \\
\hline $\begin{array}{l}\text { (Shariff et al., } \\
\text { 2019) }\end{array}$ & Fuzzy-AHP & $\begin{array}{l}\text { Eco-friendly cars } \\
\text { selection }\end{array}$ & $\begin{array}{l}\text { Affordable price, Fuel economy, Safety, Services, Design, } \\
\text { Performance, and Emission }\end{array}$ \\
\hline $\begin{array}{c}\text { (İç \& Şimşek, } \\
\text { 2019) }\end{array}$ & $\begin{array}{l}\text { Operating windo- } \\
\text { TOPSIS }\end{array}$ & $\begin{array}{l}\text { Eco-friendly cars } \\
\text { selection }\end{array}$ & $\begin{array}{l}\text { Cubic motor capacity, Fuel consumbtio, body type, } \mathrm{CO} 2 \text { emmision, } \\
\text { number of point sales, warranty, price, second hand price, and } \\
\text { Tourque }\end{array}$ \\
\hline $\begin{array}{l}\text { (Biswas \& Das, } \\
\text { 2018) }\end{array}$ & MABAC & Hyprid car selection & $\begin{array}{l}\text { Tank size, Tailpipe Emissions, Passenger volume, Vehicle cost, and } \\
\text { fuel economy }\end{array}$ \\
\hline $\begin{array}{l}\text { (Mohamadabadi } \\
\text { et al., 2009) }\end{array}$ & PROMETHEE & Car selection & $\begin{array}{l}\text { Vehicle cost, fuel cost, distance between refueling stations, number of } \\
\text { vehicle options available to the consumer, and greenhouse gas (GHG) } \\
\text { emissions per unit distance traveled }\end{array}$ \\
\hline
\end{tabular}

\subsection{Analytic Network Process Methodology}

Multiple evaluation measures are usually used in proper decision-making, and, depending on the decisionmaking problem, these measures may be interdependent, and ignoring such interdependencies may lead to a deficient decision-making process. ANP is a decision-making method that can deal with situations in which different types of interdependencies are to be considered. This method has been proven to have the capability to deal with complex decision-making problems associated with interdependencies among evaluation criteria. For example, Saaty and Vargas (2006) introduced ANP as a decision-making tool for dealing with complex economic, social, and technological decisions with different interdependencies among evaluation criteria. Al-Hawari, Mumani, and Momani (2014) also built an ANP model to select among alternative facility layouts while considering interdependent quantitative and qualitative measures. Yayla, A and Yildiz (2013) also applied a FuzzyANP models to car selection.

Other researchers have used ANP along with ELECTRE to achieve advantages. For example, Banar, Özkan and Kulaç(2015) proposed an approach for selecting the best site treatment technology for metal-contaminated soils. In that model, both ANP and ELECTRE II were utilized, and similar results were obtained from both methods. Banar, Özkan, and Kulaç (2010) also applied ANP and ELECTRE III to select the most appropriate recycling scenario, and again the results of both methods produced similar conclusions with respect to the best recycling scenario. The problem of supplier selection was also tackled by integrating modified ANP and ELECTRE III methods (Wan, Xu, \& Dong, 2017). In that study, a modified -ANP method was used to determine subcriteria 
weights, and modified ELECTRE III was used to rank the alternatives. To our knowledge, integration of ANP and ELECTRE III has not been applied to eco-friendly car selection.

The ANP method can be summarized into consecutive stages, beginning with identification of evaluation criteria and alternatives of interest. The resulting elements should then be arranged into clusters, and interdependencies among the clusters should be identified, after which the decision-making problem can be structured into a network of interdependent elements. The influence of interdependent elements should then be quantified using a proper scale. Mathematical procedures and required pairwise comparisons should then be performed to achieve limit priorities of these elements. More details on the ANP procedure and algorithm are available in (Saaty, 1999; Saaty \& Vargas, 2006), with the main stages listed below.

1- Define the decision-making problem.

2- Identify decision criteria of relevance.

3- Arrange the decision criteria into clusters.

4- Identify interdependencies among decision criteria.

5- Evaluate the relative influence of interrelated criteria on one another.

6- Build an un-weighted super matrix.

7- Evaluate the overall influence of interdependent clusters and obtain a cluster matrix.

8- Use the unweighted super matrix and the cluster matrix to obtain a weighted super matrix.

9- Raise the weighted super matrix to a high power.

10- A limit matrix with similar columns can then be produced to reflect limit priorities.

\subsection{ELECTRE III Methodology}

One of the ELECTRE decision-making family is ELECTRE III, known to be an outranking-based decisionmaking tool with capability to rank alternatives (Figueira, J. R., Greco, S., Roy, B., and Słowiński, 2013). ELECTRE III has many applications in different fields. For example, Fancello, Carta, and Fadda (2014) proposed an evaluation method based on ELECTRE III to aid in evaluating road-safety conditions, and the model helped in creating an efficient resource-allocation plan that ensures proper infrastructure improvement. ELECTRE III was also applied to solve transportation problems by ranking alternative scenarios (Richter, 2018). El Mazouri et al. (2018) also proposed an MCDM model based on ELECTRE III to determine the priority for providing electricity services to villages in Morocco. A modified version of ELECTREIII, integrating ELECTRE III with the Kano quality model, was proposed and applied a cell-phone selection problem (I. F. Chen, Tsaur, \& Chen, 2018). ELECTRE III was also used along with historical data to aid in making proper decisions regarding portfolio selection (Chanvarasuth, Boongasame, \& Boonjing, 2019). ELECTRE III was also integrated with the method of quality-function deployment to select the best alternative sustainable building material in consideration of stakeholder requirements (Z.-S. Chen et al., 2019). An MCDM model based on ELECTRE III was also used to help evaluate renewable-energy options (Peng, Shen, He, Zhang, \& Wang, 2019).

ELECTRE III is known to have capability of dealing with fuzzy decision criteria as it constructs fuzzy outranking relationships (Lizbeth, Sa, Carlos, \& Lo, 2008) by producing concordance and discordance indices for evaluating alternative options using three thresholds (Milani, Shanian, \& El-Lahham, 2006). It requires knowledge of weight of importance (w) and thresholds of indifference (q), preference, and veto (v) for each criterion. The thresholds can be selected such that $\mathrm{q} \leq \mathrm{p} \leq \mathrm{v}$ (Marzouk, 2011). The following sections will describe ELECTRE III methodology, including its stages of identifying outranking relationships and ranking alternatives (Rogers, Bruen, \& Maystre, 2000). 


\section{Outranking Relationships}

Concordance and discordance indices infer the degree of agreement or disagreement with assertions like "a outranks b". In fact, the outranking relationships are built based on these indices, as shown below.

The Concordance Index $C(a, b)$. The concordance index represents the proportion of criteria weights that agree with "a outranks b". $C(a, b) \in\left[\begin{array}{ll}0 & 1]\end{array}\right.$ and can be calculated as follows:

$$
\begin{aligned}
& \mathrm{C}(\mathrm{a}, \mathrm{b})=\frac{1}{w} \sum_{j=1}^{n} w_{j} c_{j}(a, b) \\
& w=\sum_{j=1}^{n} w_{j} \\
& \mathrm{C}_{J}(\mathrm{a}, \mathrm{b})=\left\{\begin{array}{cc}
1, \mathrm{gj}(\mathrm{a})+\mathrm{qj}(\mathrm{gj}(\mathrm{a})) \geq \mathrm{gj}(\mathrm{b}) \\
0, \mathrm{gj}(\mathrm{a})+\mathrm{pj}(\mathrm{gj}(\mathrm{a}))<g \mathrm{j}(\mathrm{b}) \\
\frac{\mathrm{g}_{j}(\mathrm{a})-\mathrm{g}_{j}(\mathrm{~b})+\mathrm{p}_{j}\left(\mathrm{~g}_{j}(\mathrm{a})\right)}{\mathrm{p}_{j}\left(\mathrm{q}_{j}(\mathrm{a})\right)-\mathrm{q}_{j}\left(\mathrm{~g}_{j}(\mathrm{a})\right)}, \quad \text { Otherwise }
\end{array}\right.
\end{aligned}
$$

is the strict threshold of criterion $\mathrm{j}$.

$\mathrm{q}_{\mathrm{j}}$ : is the indifference threshold of criterion $\mathrm{j}$.

$\mathrm{g}_{\mathrm{j}}(\mathrm{a})$ : the performance of a on criterion $\mathrm{j}$.

$\mathrm{g}_{\mathrm{j}}(\mathrm{b})$ : the performance of a on criterion $\mathrm{j}$.

$\mathrm{q}_{\mathrm{j}}\left(\mathrm{g}_{\mathrm{j}}(\mathrm{a})\right)$ : j's indifference threshold with respect to $\mathrm{a}$.

$\mathrm{p}_{\mathrm{j}}\left(\mathrm{g}_{\mathrm{j}}(\mathrm{a})\right)$ : j's preference threshold with respect to a.

The discordance index $\mathrm{D}(\mathrm{a}, \mathrm{b})$. The discordance index for a criteria $\mathrm{D}_{\mathrm{j}}(\mathrm{a}, \mathrm{b}) \in\left[\begin{array}{ll}0 & 1\end{array}\right]$ can be calculated as follows:

$$
\operatorname{Dj}(\mathrm{a}, \mathrm{b})=\left\{\begin{array}{l}
0 \text { if } \mathrm{gj}(\mathrm{a})+\operatorname{pj}(\mathrm{gj}(\mathrm{a})) \geq \mathrm{gj}(\mathrm{b}) \\
1, \mathrm{gj}(\mathrm{a})+\mathrm{vj}(\mathrm{gj}(\mathrm{a}))<g \mathrm{~g}(\mathrm{~b}) \\
\frac{\mathrm{g}_{j}(\mathrm{~b})-\mathrm{g}_{j}(\mathrm{a})-\mathrm{p}_{j}\left(\mathrm{~g}_{j}(\mathrm{a})\right)}{\mathrm{v}_{j}\left(\mathrm{~g}_{j}(\mathrm{a})\right)-\mathrm{P}_{j}\left(\mathrm{~g}_{j}(\mathrm{a})\right)}, \text { Otherwise }
\end{array}\right.
$$

$\mathrm{v}_{\mathrm{j}}\left(\mathrm{g}_{\mathrm{j}}(\mathrm{a})\right)$ is the $\mathrm{jth}$ criterion veto threshold with respect to $\mathrm{a}$.

Credibility Score. To combine $\mathrm{C}_{\mathrm{j}}(\mathrm{a}, \mathrm{b})$ and $\mathrm{D}_{\mathrm{j}}(\mathrm{a}, \mathrm{b})$ into a single measure, ELECTRE III generates what is called a credibility score $\mathrm{S}(\mathrm{a}, \mathrm{b})$. In general, if the discordance indices are less than the concordance index, the concordance index will remain the same. However, if this is not the case, the concordance index value will be diminished. This score measures overall conformance with " a outranks b" and can be calculated as follows:

$$
S(a, b)=\left\{\begin{array}{l}
C(a, b), \quad D j(a, b) \leq C(a, b) \text {, for all } j \\
C(a, b) \prod_{j \in J(a, b)} \frac{\left(1-D_{j}(a, b)\right)}{1-C(a, b)}, \text { Otherwise }
\end{array}\right.
$$

Utilizing the Outranking Relations. The identified outranking relationships can then be utilized to rank the alternatives under evaluation, and the ranking process can be described as a sequential distillation process leading to ranked alternatives. Downward and upward distillation methods are performed to obtain alternative rankings, and 
to that end a qualification score should be identified for each option. The detailed steps of the ranking process can be described as follows.

Step 1: Identification of $\lambda_{0}$

$\lambda_{\mathrm{o}}=\max \{\mathrm{S}(\mathrm{a}, \mathrm{b})\} \forall \mathrm{a}, \mathrm{b} \in \mathrm{A}$

Step 2: Identification of the cutoff value $\lambda_{1}$

$\lambda_{1}=\lambda_{0}-\mathrm{S}\left(\lambda_{0}\right)$

where $\mathrm{S}\left(\lambda_{0}\right)$ is the threshold value that can discriminate between alternatives.

Accordingly, it can be stated that a outranks $b$ at $\lambda_{1}$ such that

a $S \lambda_{1} b$ Iff $S(a, b)>\lambda_{1}$ and $S(a, b)-S(b, a)>S(s(a, b))$,

where $S(\lambda)=\alpha \lambda-\beta$.

\section{Step 3: The Qualification Score}

To determine the qualification score of an option $\left(q_{A}^{\lambda 1}(\mathrm{a})\right)$, its strength $P_{A}^{\lambda 1}$ (a) and weakness $f_{A}^{\lambda 1}$ (a) must be evaluated as follows:

$\left(q_{A}^{\lambda 1}(\mathrm{a})\right)=P_{A}^{\lambda 1}(\mathrm{a})-f_{A}^{\lambda 1}(\mathrm{a})$

Where

$P_{A}^{\lambda 1}(\mathrm{a})=\left|\left\{\mathrm{b} \in \mathrm{A} / \mathrm{a} S_{A}^{\lambda 1} \mathrm{~b}\right\}\right|$,

$f_{A}^{\lambda 1}(\mathrm{a})=\left|\left\{b \in A / b S_{A}^{\lambda 1} \mathrm{a}\right\}\right|$.

\section{Step 4: Downward Method}

A subset of the best options with highest qualification scores is then created and can be described as follows:

$\overline{\mathrm{D} 1}=\left\{\mathrm{a} \in \mathrm{A} / \mathrm{q}_{\mathrm{A}}{ }^{\lambda 1}\right\}=\operatorname{Max} \mathrm{q}_{\mathrm{A}}{ }^{\lambda 1}(\mathrm{x}), \mathrm{x} \in \mathrm{A}$

For alternatives in $\overline{\mathrm{D} 1}$, the process of distillation is repeated with a reduced cutoff value. The distillation process proceeds until only either one option remains in $\overrightarrow{\mathrm{D} 1}$ or the cutoff value approaches 0 . In case of two alternatives resulting from a distillation process, they are considered to have the same rank. The cutoff value for each distillation step can be determined using the following equation:

$$
\lambda_{\mathrm{k}+1}=\operatorname{Max}\left(\mathrm{S}(\mathrm{a}, \mathrm{b})<\lambda_{\mathrm{k}}-\mathrm{S}\left(\lambda_{\mathrm{k}}\right) ; \mathrm{a}, \mathrm{b} \in \mathrm{D}_{\mathrm{k}}\right)
$$

The next step of distillation continues with the remaining unranked alternatives, and $\lambda_{0}$ can be calculated based on them. The distillation process continues until all alternatives are ranked.

Step 5: Upward Method

The subset $\mathrm{D} 1$ of the worst options, those having the lowest qualification scores, can be determined as follows: 
$\underline{\mathrm{D} 1}=\left\{\mathrm{a} \in \mathrm{A} / \mathrm{qA}^{\lambda 1}\right\}=\operatorname{Min} \mathrm{qA}^{\lambda 1}, \mathrm{x} \in \mathrm{A}$

Alternatives with minimum qualification scores are drawn each distillation step, and the process continues until either only one option remains in D1 or the cutoff value approaches 0 . A similar procedure will be followed as in the Downward method.

\section{Step 6: Final Ranking}

The alternative ranking resulting from both downward and upward methods is then combined to produce a final ranking.

\section{METHODOLOGY}

The integrated decision-making framework is comprised of ANP and ELECTRE III. Since performance measures of green-friendly cars are to be identified and categorized into homogeneous clusters, previous related research can be surveyed, and proper evaluation measures can be selected and further categorized. Interdependencies between these measures should then be determined and evaluated in terms of weights of influence on one another. A network structure of performance measures arranged in clusters and connected through influence arrows can be built, and it required pairwise comparisons performed to allow determining limit priorities to be used to represent steady-state priorities of performance measures. Alternative cars should then be identified and evaluated based on these evaluation measures, and thresholds of preferences identified to produce outranking relationships. The ELECTRE III procedure is followed to rank car alternatives. Figure 1 is a flow chart of the methodology.

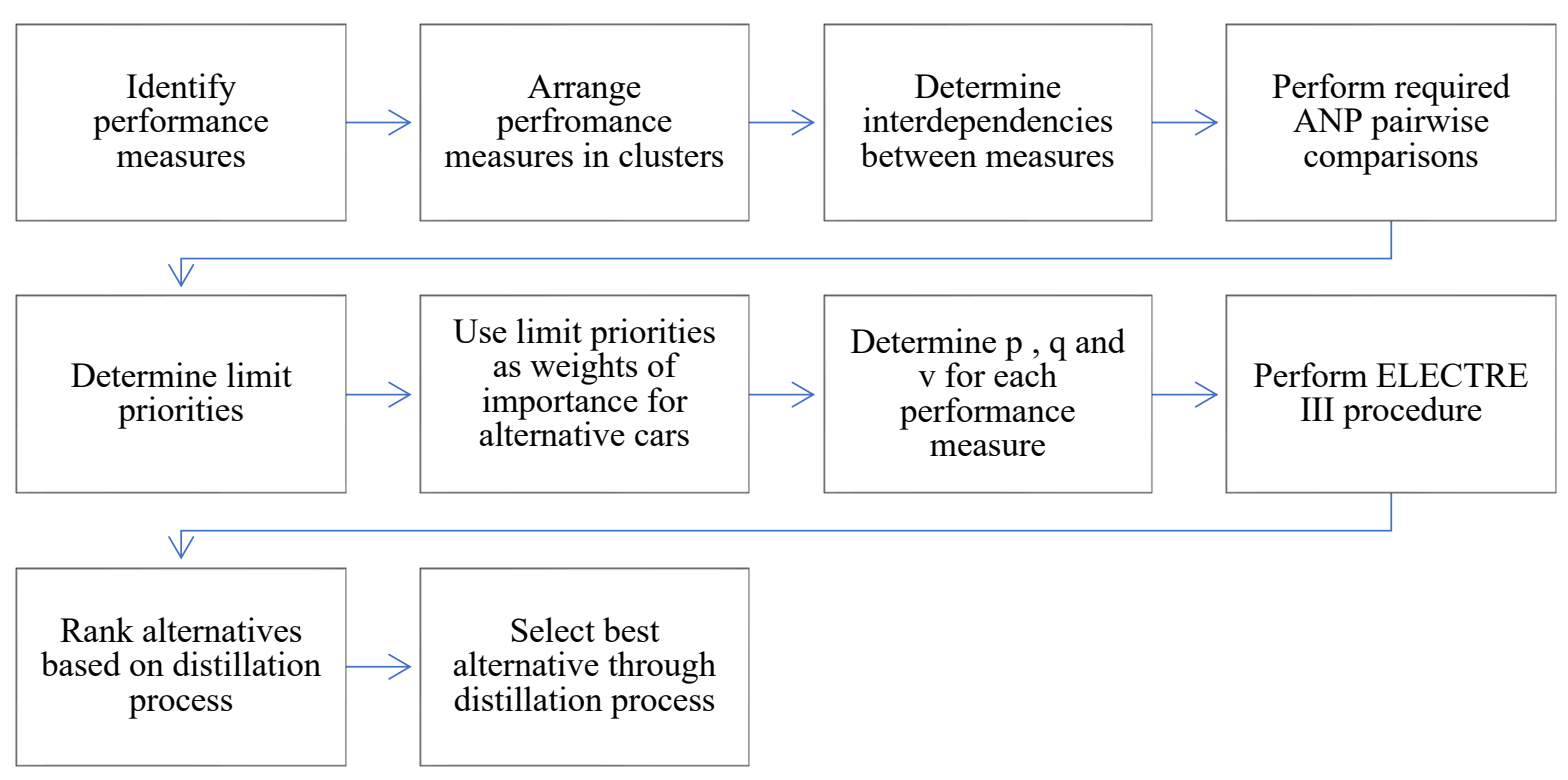

Figure 1. Methodology flow chart. 


\subsection{Case Study}

To demonstrate the model, a case study of selecting an eco-friendly car among five alternatives is presented, with hybrid Toyota Prius, hybrid Ford Fusion, hybrid Hyundai Sonata, electrical Nissan Leaf, and electrical BMW i3 considered as alternatives that are well known to customers and available in the market. An expert extracted twenty-eight decision criteria from the literature (Table 1) and verified them to ensure their suitability for the case under study. Homogenous criteria were then categorized into the five clusters shown in Table 2. Interdependencies between decision criteria were identified along with their influences to produce the ANP structure shown in Figure 2. The process of clustering and identifying interdependencies was performed in consecutive sessions. Required pairwise comparisons were then performed by the expert to obtain limit priorities from the ANP model as shown in Table 2.

Table 2. Decision criteria arranged in clusters.

\begin{tabular}{|c|c|c|}
\hline Cluster & Decision Criteria & Limit priorities \\
\hline \multirow{5}{*}{ Economics } & Fuel consumption $\backslash$ distance per full charge battery & 0.1559 \\
\hline & Maintenance cost & 0.0190 \\
\hline & Operations cost: Taxes \&insurance & 0.0126 \\
\hline & Price & 0.2848 \\
\hline & Resale & 0.0047 \\
\hline \multirow{4}{*}{$\begin{array}{c}\text { Features and } \\
\text { Technology }\end{array}$} & Accessories and features & 0.0152 \\
\hline & Aesthetic & 0.0036 \\
\hline & Smart systems & 0.0131 \\
\hline & Technologies & 0.0417 \\
\hline \multirow{6}{*}{ Performance } & Acceleration & 0.0171 \\
\hline & Braking & 0.0155 \\
\hline & Comfort & 0.0195 \\
\hline & Engine power and torque & 0.0667 \\
\hline & Fuel tank capacity/Full battery charge & 0.0066 \\
\hline & Speed & 0.0538 \\
\hline
\end{tabular}




\begin{tabular}{|l|l|c|}
\hline \multirow{4}{*}{ Quality } & Accessibility and Efficiency & 0.0071 \\
\cline { 2 - 3 } & Convenience & 0.0228 \\
\cline { 2 - 3 } & Emission & 0.0065 \\
\cline { 2 - 3 } & Exterior & 0.0137 \\
\cline { 2 - 3 } Flexibility and warranty & 0.0306 \\
\cline { 2 - 3 } & Manufacturers & 0.0630 \\
\cline { 2 - 3 } & Reliability & 0.0672 \\
\hline \multirow{4}{*}{ Safety } & ABS & 0.0132 \\
\cline { 2 - 3 } & Airbag & 0.0056 \\
\cline { 2 - 3 } & Auto escape and Life-Saving Tool & 0.0049 \\
\cline { 2 - 3 } & Body alarm & 0.0057 \\
\cline { 2 - 3 } & Road holding & 0.0242 \\
\cline { 2 - 3 } & Seat belt & 0.0057 \\
\hline
\end{tabular}

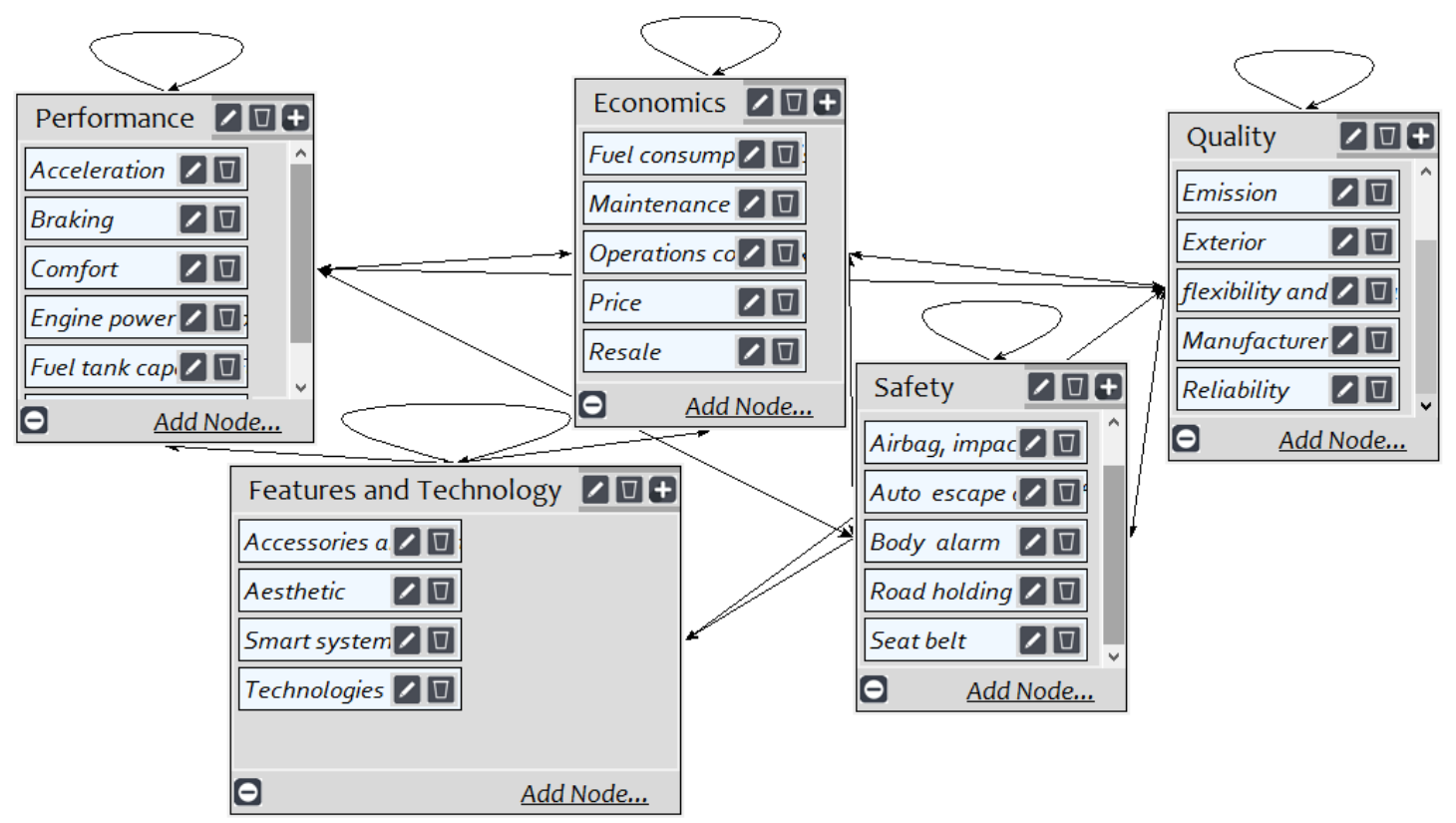

Figure 2. A network structure of the selection problem. 
Limit priorities obtained from ANP then can be used as ELECTRE III inputs $\left(w_{j}\right)$. Because of variability among car dealers and selling used cars in most cases, subjective measures were used to evaluate alternative cars. Alternative cars were evaluated with insights on car specifications, available data on the internet, consumer reviews, car rate by ownerships, and general service centers (general car repair shops).A swing-weighing method (Kenneth Chelst, 2011) was used to evaluate alternative cars with respect to evaluation criteria. For each performance measure, the alternatives were ranked, with the best alternative ranked first and assigned a score of 100 , with the following alternatives assigned lower scores. For each decision criterion, indifference and preference values were identified as shown in Table 3 .

The data presented in Tables 2 and 3 were used to perform ELECTRE III using J-Electre-v2.0 software, and ELECRE III produced an upward and downward ranking through a distillation process, with average rankings shown in Table 4 and then calculated. These results state that Toyota Prius, Ford Fusion, and Nissan Leaf were ranked first based on the used decision criteria, weights of importance and preference, and indifference values, while BMW i3 and Hyundai Sonata were respectively ranked second and third. When a veto value equal to the preference value for each decision criteria is considered, ELECTRE III produced more distinguishable results in which the Toyota Prius was ranked first, followed by Nissan Leaf, Hyundai Sonata, Ford Fusion, and BMW i3.

The alternatives were ranked based on the ANP method, in which limit priorities of evaluation criteria were multiplied by their corresponding alternative's performance, and the summation of these multiplications resulted in an overall alternative score for each alternative car. These scores were then used to rank the alternatives. Nissan Leaf was ranked first, followed by BMW i3, Toyota Prius, Ford Fusion, and Hyundai Sonata, as shown in Table 4.

Table 3. Performance of alternative eco-friendly cars.

\begin{tabular}{|l|c|c|c|c|c|c|c|}
\hline Decision Criteria & $\begin{array}{c}\text { Indifference } \\
(\mathrm{q})\end{array}$ & $\begin{array}{c}\text { Preference } \\
(\mathrm{p})\end{array}$ & $\begin{array}{c}\text { Toyota } \\
\text { Prius }\end{array}$ & $\begin{array}{c}\text { Ford } \\
\text { Fusion }\end{array}$ & $\begin{array}{c}\text { Hyundai } \\
\text { Sonata }\end{array}$ & $\begin{array}{c}\text { Nissan } \\
\text { Leaf }\end{array}$ & $\begin{array}{c}\text { BMW } \\
\text { i3 }\end{array}$ \\
\hline $\begin{array}{l}\text { Fuel consumption } \text { (distance } \\
\text { per full charge battery }\end{array}$ & 5 & 16 & 84 & 91 & 86 & 100 & 97 \\
\hline Maintenance cost & 10 & 31 & 83 & 88 & 85 & 100 & 94 \\
\hline $\begin{array}{l}\text { Operations cost: Taxes } \\
\text { \&insurance }\end{array}$ & 25 & 75 & 63 & 50 & 50 & 100 & 88 \\
\hline Price & 1 & 3 & 94 & 89 & 90 & 100 & 91 \\
\hline Resale & 4 & 12 & 92 & 100 & 90 & 96 & 94 \\
\hline Accessories and features & 19 & 58 & 96 & 100 & 100 & 96 & 92 \\
\hline Aesthetic & 26 & 78 & 81 & 100 & 100 & 74 & 78 \\
\hline Smart systems & 42 & 83 & 100 & 92 & 92 & 83 & 92 \\
\hline
\end{tabular}




\begin{tabular}{|c|c|c|c|c|c|c|c|}
\hline Technologies & 31 & 92 & 92 & 77 & 85 & 77 & 100 \\
\hline Acceleration & 8 & 24 & 100 & 95 & 100 & 74 & 74 \\
\hline Braking & 8 & 24 & 100 & 100 & 100 & 100 & 100 \\
\hline Comfort & 25 & 75 & 80 & 78 & 75 & 100 & 100 \\
\hline Engine power and torque & 13 & 40 & 89 & 100 & 93 & 78 & 82 \\
\hline $\begin{array}{l}\text { Fuel tank capacity/Full } \\
\text { battery charge }\end{array}$ & 7 & 22 & 100 & 96 & 93 & 78 & 74 \\
\hline Speed & 4 & 11 & 93 & 100 & 96 & 74 & 78 \\
\hline Accessibility and Efficiency & 11 & 32 & 100 & 97 & 97 & 84 & 82 \\
\hline Convenience & 28 & 56 & 72 & 94 & 100 & 94 & 83 \\
\hline Emission & 25 & 75 & 75 & 75 & 75 & 100 & 100 \\
\hline Exterior & 14 & 29 & 89 & 100 & 100 & 86 & 89 \\
\hline flexibility and warranty & 24 & 48 & 98 & 95 & 93 & 100 & 95 \\
\hline Manufacturers & 7 & 21 & 100 & 93 & 79 & 93 & 97 \\
\hline Reliability & 24 & 48 & 98 & 95 & 93 & 100 & 95 \\
\hline ABS & 5 & 8 & 100 & 100 & 100 & 100 & 100 \\
\hline Airbag & 25 & 50 & 100 & 100 & 100 & 100 & 100 \\
\hline $\begin{array}{l}\text { Auto escape and Life-Saving } \\
\text { Tool }\end{array}$ & 30 & 40 & 100 & 100 & 100 & 100 & 100 \\
\hline Body alarm & 50 & 83 & 83 & 67 & 100 & 50 & 67 \\
\hline Road holding & 11 & 32 & 96 & 100 & 93 & 96 & 96 \\
\hline Seat belt & 17 & 50 & 100 & 100 & 100 & 100 & 100 \\
\hline
\end{tabular}


Table 4. Alternatives' Ranking using ELECTRE III and ANP.

\begin{tabular}{|c|c|c|c|c|c|c|c|c|}
\hline & \multicolumn{2}{|c|}{ ELECTRE III Without Veto } & \multicolumn{2}{c|}{$\begin{array}{c}\text { ELECTRE III With } \\
\text { veto=Preference }\end{array}$} & \multicolumn{2}{c|}{ ANP } \\
\hline Alternative & Upward & Downward & Average & Upward & Downward & Average & Score & Rank \\
\hline Toyota Prius & 1.0 & 1.0 & 1.0 & 1.0 & 1.0 & 1.0 & 0.916656 & 3 \\
\hline Ford Fusion & 1.0 & 1.0 & 1.0 & 2.0 & 3.0 & 2.5 & 0.915606 & 4 \\
\hline $\begin{array}{c}\text { Hyundai } \\
\text { Sonata }\end{array}$ & 3.0 & 2.0 & 2.5 & 2.0 & 2.0 & 2.0 & 0.896993 & 5 \\
\hline Nissan Leaf & 1.0 & 1.0 & 1.0 & 1.0 & 2.0 & 1.5 & 0.939237 & 1 \\
\hline BMW i3 & 2.0 & 2.0 & 2.0 & 3.0 & 4.0 & 3.5 & 0.917402 & 2 \\
\hline
\end{tabular}

\subsection{Sensitivity Analysis}

The priorities obtained from the ANP model are highly dependent on subjective judgments, which may be associated with uncertainties. Such uncertainties are also associated with the used thresholds. Accordingly, there is a need to observe the robustness of the resulting ranking when these priorities and thresholds change. To that end, sensitivity analysis was conducted on the criteria with the highest priorities resulting from the ANP model and on the thresholds used in the ELECTRE III model. The priorities have been manipulated by increasing and decreasing the original values by $10 \%, 20 \%, 30 \%$, and $40 \%$. The priority of each criterion was manipulated separately, while the deviations from original values were distributed to the remaining criteria based on their relative priorities to ensure that the weights add to one. The sensitivity analysis resulted in eight different setups in addition to the original one as shown in Table 5. Under each setup, alternatives' ranking was reported to determine the robustness of those ranking.

The thresholds used in ELECTRE III were also manipulated for the criteria with the highest priorities by increasing and decreasing the original thresholds of a criterion by $10 \%, 20 \%, 30 \%$, and $40 \%$. While manipulating the thresholds for a criterion, other thresholds used for the remaining criteria were fixed. Under each setup, the ranking of the alternatives was reported with a summary of the results shown in Table 6. The results obtained from the sensitivity analysis showed the robustness of the model, in which the alternatives' ranking showed no noticeable changes under the setups under study. 
Table 5. Sensitivity analysis with average ranking under different priorities when applying a veto.

\begin{tabular}{|c|c|c|c|c|c|c|c|c|c|c|}
\hline Criteria & Alternatives & Original & $-10 \%$ & $10 \%$ & $-20 \%$ & $20 \%$ & $-30 \%$ & $30 \%$ & $-40 \%$ & $40 \%$ \\
\hline \multirow{5}{*}{ 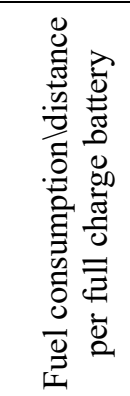 } & Toyota Prius & 1.0 & 1.0 & 1.0 & 1.0 & 1.0 & 1.0 & 1.0 & 1.0 & 1.0 \\
\hline & Ford Fusion & 2.5 & 2.5 & 2.5 & 2.5 & 2.5 & 2.5 & 2.5 & 2.5 & 2.5 \\
\hline & Hyundai Sonata & 2.0 & 2.0 & 2.0 & 2.0 & 2.5 & 2.0 & 2.5 & 2.0 & 2.5 \\
\hline & Nissan Leaf & 1.5 & 1.5 & 1.5 & 1.5 & 1.5 & 1.5 & 1.5 & 1.5 & 1.5 \\
\hline & BMW i3 & 3.5 & 3.5 & 3.5 & 3.5 & 3.5 & 3.5 & 3.5 & 3.5 & 3.5 \\
\hline \multirow{5}{*}{ 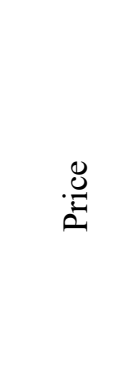 } & Toyota Prius & 1.0 & 1.0 & 1.0 & 1.0 & 1.0 & 1.0 & 1.0 & 1.0 & 1.0 \\
\hline & Ford Fusion & 2.5 & 2.0 & 2.5 & 2.0 & 2.5 & 2.0 & 2.5 & 2.0 & 2.5 \\
\hline & Hyundai Sonata & 2 & 2.0 & 2.0 & 2.0 & 2.0 & 2.5 & 2.0 & 2.5 & 2.0 \\
\hline & Nissan Leaf & 1.5 & 1.5 & 1.5 & 1.5 & 1.5 & 1.5 & 1.5 & 1.5 & 1.5 \\
\hline & BMW i3 & 3.5 & 3.0 & 3.5 & 3.0 & 3.5 & 3.5 & 3.5 & 3.5 & 3.5 \\
\hline
\end{tabular}

Table 6. Sensitivity analysis with average ranking under different thresholds when applying a veto.

\begin{tabular}{|c|c|c|c|c|c|c|c|c|c|c|}
\hline \multirow{6}{*}{ 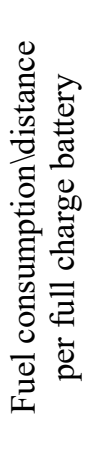 } & Alternatives & Original & $-10 \%$ & $10 \%$ & $-20 \%$ & $20 \%$ & $-30 \%$ & $30 \%$ & $-40 \%$ & $40 \%$ \\
\hline & Toyota Prius & 1.0 & 1.0 & 1.0 & 1.0 & 1.0 & 1.0 & 1.0 & 1.0 & 1.0 \\
\hline & Ford Fusion & 2.5 & 2.5 & 2.5 & 2.5 & 2.0 & 2.5 & 2.0 & 2.5 & 2.0 \\
\hline & Hyundai Sonata & 2.0 & 2.5 & 2.0 & 2.5 & 2.0 & 2.5 & 2.0 & 3.0 & 2.0 \\
\hline & Nissan Leaf & 1.5 & 1.5 & 1.5 & 1.5 & 1.5 & 1.5 & 1.5 & 1.5 & 1.5 \\
\hline & BMW i3 & 3.5 & 3.5 & 3.5 & 3.5 & 3.0 & 3.5 & 3.0 & 3.5 & 3.0 \\
\hline \multirow{5}{*}{$\stackrel{\circlearrowright}{\stackrel{e}{\Xi}}$} & Toyota Prius & 1.0 & 1.0 & 1.0 & 1.0 & 1.0 & 1.0 & 1.0 & 1.0 & 1.0 \\
\hline & Ford Fusion & 2.5 & 3.0 & 2.0 & 3.0 & 2.0 & 2.5 & 2.0 & 3.0 & 2.0 \\
\hline & Hyundai Sonata & 2.0 & 2.5 & 2.0 & 2.5 & 2.0 & 2.5 & 2.0 & 2.5 & 2.0 \\
\hline & Nissan Leaf & 1.5 & 1.5 & 1.5 & 1.5 & 1.5 & 1.5 & 1.5 & 1.5 & 1.5 \\
\hline & BMW i3 & 3.5 & 4.0 & 3.0 & 4.0 & 3.0 & 3.5 & 3.0 & 3.5 & 3.0 \\
\hline
\end{tabular}




\section{DISCUSSION}

The proposed integrated model was presented and applied to a case study focused on selecting an alternative eco-friendly car among five alternatives. ANP was initially applied to determine the relative weights of importance of the decision criteria, and these weights were then used with required thresholds to perform ELECTRE III. The results produced by the model were presented in terms of an alternative ranking in which the best alternative was ranked first

Based on the ANP model, selling price and fuel consumptionldistance per full charge battery were assigned to have the highest level of priority compared to the rest of the evaluation criteria. In fact, this result represented the market in which the fuel prices are high compared to individual income, and where cars are sold at high prices. Accordingly, while consumers are usually looking for an affordable car with efficient fuel consumption, criteria importance may differ depending on the case under evaluation. For example, fuel prices may not be of as much concern as selling price in another country.

To perform ELECTRE III, weights of importance should be determined along with appropriate thresholds of preference. ANP limit priorities were used to represent weights of relative importance of the evaluation criteria, while other preferences were determined for each evaluation criteria. ELECTRE III was performed both with no veto assigned for any evaluation criteria and with a veto value for each criterion. With no veto values considered, the model results reflected the superiority of the Toyota Prius-Ford Fusion and Nissan Leaf, ranked first, over BMW i3, and Hyundai Sonata ranked last. When applying a veto value to each performance measure, the model resulted in a distinguishable ranking for each alternative, with the Toyota Prius ranked first and the BMW i3 ranked last, as shown in Table 3. In fact, the veto value was able to produce a comparable result since it produced a distinct ranking for each alternative. Sensitivity analysis showed the robustness of the model under different setups when applying a veto value.

To evaluate the performance of ELECTRE III, results obtained from ANP and Idealized values of alternative performances were presented. Overall alternative performances were very close to one another, with only tiny differences, making these alternatives virtually indistinguishable, so this ranking would not help users make a decision regarding their future car. In fact, given the similarities between the alternative cars, this result would be expected to happen. However, in the case of using ELECTRE III with veto thresholds, the alternatives were distinguishable even in this situation. It is worth mentioning that ANP resulted in an alternative ranking differing from that of ELECTRE III, in which Nissan Leaf was ranked first, followed by BMW i3, Toyota Prius, Ford Fusion, and Hyundai Sonata, an unreasonable result in the context of the market.

The case study presented is taken from a market that has experienced a noticeable increase in the number of eco-friendly cars, especially the five alternatives of this study. The model presented can be implemented to select any type of cars with a modified set of decision criteria and alternatives. The preferences presented in the model are relevant only to the market under study and may be subject to change if based on other cases. Even with the advantages associated with the use of ANP, an increase in the number of evaluation criteria is usually associated with more complexities in terms of identifying interdependencies and the weights of influence.

\section{CONCLUSIONS}

In this paper, an integration of ANP and ELECTRE III has been introduced as a decision-making framework that aids in assessing eco-friendly cars. The decision-making problem was structured into a network of interdependent evaluation criteria that allowed consideration of types of interdependencies among decision criteria and results reflecting more realistic evaluation. The ANP model was applied to obtain limit priorities that were then 
used to perform ELECTRE III. ELECTRE III had the advantage of ranking alternatives based on indifference, preference, and veto thresholds, with capabilities for handling uncertainties. This integration between ANP and ELECTRE III assured the benefits of evaluating alternative cars based on interdependent decision criteria including thresholds of preferences. In fact, this study is the first to provide a comprehensive framework for selecting ecofriendly cars.

The model presented can help users make proper decisions regarding car purchase options. The model is comprehensive with a wide range of evaluation criteria that should be considered during the selection process. In addition, consideration of interdependencies among criteria handled complexities associated with car evaluation. Both manufacturers and dealers can benefit from the use of the ANP model to determine the most important factors that affect user-purchase decisions. In addition, the integration between ANP and ELECTRE III seems promising in solving complex decision-making problem.

As future work, eco-friendly cars could be evaluated using other methods such as preference-selection index, grey rational methods, and fuzzy-set theory. Agent-based modeling can also be used to help understand the behavior of eco-friendly users, given scenarios related to the surrounding environment. Logistic regression can also be proposed for use in understanding the preferences of users with respect to eco-friendly cars. In addition, a decision tree will be structured to help users select proper eco-friendly cars in an environment of uncertainties. Monte-Carlo simulation will also be integrated with a decision tree to cope with uncertainties experienced in the market

\section{REFERENCES}

Al-Hawari, T., Mumani, A., \& Momani, A. 2014. Application of the Analytic Network Process to facility layout selection. Journal of Manufacturing Systems, 33(4), 488-497. https://doi.org/10.1016/j.jmsy.2014.04.006

Anandh, K., \& Sundar, D. K. S. 2014. Factors Affecting Consumer's Brand Preference of Small Cars. IOSR Journal of Business and Management, 16(5), 43-47. https://doi.org/10.9790/487x-16534347

Apak, S., Göğüus, G. G., \& Karakadılar, İ. S. 2012. An Analytic Hierarchy Process Approach with a Novel Framework for Luxury Car Selection. Procedia - Social and Behavioral Sciences, 58, 1301-1308. https://doi.org/10.1016/j.sbspro.2012.09.1113

Banar, M., Özkan, A., \& Kulaç, A. 2010. Choosing a recycling system using ANP and ELECTRE III techniques. Turkish Journal of Engineering and Environmental Sciences, 34(3), 145-154. https://doi.org/10.3906/muh-0906-47

Belgiawan, P. F., Schmöcker, J.-D., \& Fujii, S. 2013. Effects of Peer Influence, Satisfaction and Regret on Car Purchase Desire. Procedia Environmental Sciences, 17, 485-493. https://doi.org/10.1016/j.proenv.2013.02.063

Biswas, T. K., \& Das, M. C. 2018. Selection of hybrid vehicle for green environment using multi-attributive border approximation area comparison method. Management Science Letters, 8(2), 121-130. https://doi.org/10.5267/j.msl.2017.11.004

Biswas, T. K., \& Saha, P. 2019. Selection of commercially available scooters by new MCDM method. International Journal of Data and Network Science, 3, 137-144. https://doi.org/10.5267/j.ijdns.2018.12.002 
Byun, D. H. 2001. The AHP approach for selecting an automobile purchase model. Information and Management, 38(5), 289-297. https://doi.org/10.1016/S0378-7206(00)00071-9

Chand, M., \& Avikal, S. 2016. An MCDM based approach for purchasing a car from Indian car market. 4th Students Conference on Engineering and Systems, SCES 2015, 8-11. https://doi.org/10.1109/SCES.2015.7506454

Chanvarasuth, P., Boongasame, L., \& Boonjing, V. 2019. An ELECTRE III Based CBR Approach to Combinatorial Portfolio Selection. Asia-Pacific Journal of Financial Studies, 48(3), 386-409. https://doi.org/10.1111/ajfs.12260

Jamil, F. C., \& Aminuddin, A. S. A. 2019. Preliminary study of Malaysian eco-friendly car selection by using analytic hierarchy process. Journal of Physics: Conference Series, 1218(1). https://doi.org/10.1088/1742$6596 / 1218 / 1 / 012022$

Chen, I. F., Tsaur, R. C., \& Chen, P. Y. 2018. Selection of best smartphone using revised ELECTRE-III method. International Journal of Information Technology and Decision Making, 17(6), 1915-1936. https://doi.org/10.1142/S0219622018500505

Chen, Z.-S., Martínez, L., Chang, J.-P., Wang, X.-J., Xionge, S.-H., \& Chin, K.-S. 2019. Sustainable building material selection: A QFD- and ELECTRE III-embedded hybrid MCGDM approach with consensus building. Engineering Applications of Artificial Intelligence, 85(December 2018), 783-807. https://doi.org/10.1016/j.engappai.2019.08.006

Chowdhury, M., Salam, K., \& Tay, R. 2016. Marketing Intelligence \&amp; Planning Consumer preferences and policy implications for the green car market. Marketing Intelligence \& Planning Iss, 34(6), 863-882.

El Mazouri, F. Z., Abounaima, M. C., Zenkouar, K., \& El Hilali Alaoui, A. 2018. Application of the ELECTRE III method at the moroccan rural electrification program. International Journal of Electrical and Computer Engineering, 8(5), 3285-3295. https://doi.org/10.11591/ijece.v8i5.pp3285-3295

Fancello, G., Carta, M., \& Fadda, P. 2014. A decision support system based on electre III for safety analysis in a suburban road network. Transportation Research Procedia, 3(July 2014), 175-184. https://doi.org/10.1016/j.trpro.2014.10.103

Fenwick, D., \& Daim, T. U. 2011. Choosing a hybrid car using a hierarchical decision model. International Journal of Sustainable Society, 3(3), 243-257. https://doi.org/10.1504/IJSSOC.2011.041266

Figueira, J. R., Greco, S., Roy, B., Słowiński, R. 2013. An Overview of ELECTRE Methods and their Recent Extensions. Journal of Multi-Criteria Decision Analysis, 26, 61-85. https://doi.org/10.1002/mcda

Mangindaan, F., Saerang, D. P., \& Tumiwa, J. 2017. CONSUMER PREFERENCES OF OFFROAD DOUBLE CABIN VEHICLE IN MANADO USING AHP METHOD (CASE STUDY: TOYOTA HILUX, ISUZU D-MAX AND MITSUBISHI STRADA TRITON). Jurnal EMBA, 5(2), 2426-2436.

Tumuju, G. F., Lapian, S. J., \& Tumbuan, W. A. 2017. ANALYSIS OF CONSUMER PREFERENCE OF SUV CAR IN MANADO USING ANALYTICAL HIERARCHY PROCESS (AHP) METHOD (CASE STUDY BETWEEN TOYOTA FORTUNER, MITSUBISHI PAJERO, AND HONDA CRV). Jurnal $E M B A, 5(2), 1901-1909$. 
İç, Y. T., \& Şimşek, E. 2019. Operating window perspective integrated TOPSIS approach for hybrid electrical automobile selection. SN Applied Sciences, 1(11). https://doi.org/10.1007/s42452-019-1357-8

Ishak, N. M., Malingam, S. D., \& Mansor, M. R. 2016. Selection of natural fibre reinforced composites using fuzzy VIKOR for car front hood. International Journal of Materials and Product Technology, https://doi.org/10.1504/IJMPT.2016.10000368

Kele, M. K. 2019. ENTROPI TEMELLI ELECTRE III YÖNTEMI ILE B USE OF ENTROPY-BASED ELECTRE III METHOD TO RANK B-SEGMENT CAR BRANDS. (33), 29-50.

Kenneth Chelst, Y. B. C. 2011. Value-added decision making for managers. CRC Press.

Lee, S. L., Chen, P. C., Chan, W. C., \& Hung, S. W. 2015. A three-stage decision-making model for selecting electric vehicle battery technology. Transportation Planning and Technology, 38(7), 761-776. https://doi.org/10.1080/03081060.2015.1059122

Lizbeth, F., Sa, D., Carlos, J., \& Lo, L. 2008. A multicriteria decision support system with an evolutionary algorithm for deriving final ranking from a fuzzy outranking relation. Oper Res Int J, 8, 47-62. https://doi.org/10.1007/s12351-008-0006-6

Marzouk, M. M. 2011. ELECTRE III model for value engineering applications. Automation in Construction, 20(5), 596-600. https://doi.org/10.1016/j.autcon.2010.11.026

Milani, A. S., Shanian, A., \& El-Lahham, C. 2006. Using different ELECTRE methods in strategic planning in the presence of human behavioral resistance. Journal of Applied Mathematics and Decision Sciences, 2006(June), 1-19. https://doi.org/10.1155/JAMDS/2006/10936

Banar, M., Özkan, A., \& Kulaç, A. 2015. Application of ANP And ELECTRE for the Assessment of Different Site Remediation Technologies. Proceedings of the World Congress on New Technologies (NewTech 2015), (151), 1-5. Barcelona, Spain.

Hamurcu, M., \& Eren, T. 2018. A HYBRID APPROACH OF ANALYTIC HIERARCHY PROCESS-TOPSIS AND GOAL PROGRAMMING FOR ELECTRIC AUTOMOBILE SELECTION. The 2018 International Conference of the African, 2.

Mendoza, P. 2018. Electric Vehicle Uptake In The Kingdom Of Thailand: Analysis Using Analytic Hierarchy Process. Sripatum University.

Davey, P., \& Balakrishnan, L.2017. A Study On Factors Influencing Brand Preferences Among Baby Boomers And Generation Y Buyers In Passenger Car Segment Focussing Chennai Region. International Journal of Management Sciences and Business Research, 6(4), 19-32.

Peng, H. G., Shen, K. W., He, S. S., Zhang, H. Y., \& Wang, J. Q. 2019. Investment risk evaluation for new energy resources: An integrated decision support model based on regret theory and ELECTRE III. Energy Conversion and Management, 183(January), 332-348. https://doi.org/10.1016/j.enconman.2019.01.015

Prakash, A., \& Mohanty, R. P. 2017. DEA and Monte Carlo simulation approach towards green car selection. Benchmarking, 24(5), 1234-1252. https://doi.org/10.1108/BIJ-11-2015-0112 
Ranscombe, C., Hicks, B., Mullineux, G., \& Singh, B.Characterizing and Evaluating Aesthetic Features in Vehicle., 2011.

Richter, M. 2018. A multi-criteria appraisal of the selection of means of urban passenger transport using the Electre and AHP methods. Czasopismo Techniczne, 6(Mcdm), 79-93. https://doi.org/10.4467/2353737xct.18.088.8693

Rihab, A., Naourez, B. H., Mohamed, C., \& Rafik, N. (2021). Multiobjective optimisation of a series hybrid electric vehicle using DIRECT algorithm. Journal of Engineering Research (Kuwait), 9(1), 151-167. https://doi.org/10.36909/JER.V9I1.8366

Rogers, M., Bruen, M., \& Maystre, L.-Y. 2000. ELECTRE and Decision Support: Methods and Applications in Engineering and Infrastructure Investment. In ELECTRE and Decision Support. https://doi.org/10.1007/978-1-4757-5057-7

Singh, R., \& Avikal, S. 2019. A MCDM-Based Approach for Selection of a Sedan Car from Indian Car Market. Harmony Search and Nature Inspired Optimization Algorithms, 741, 569-578. https://doi.org/10.1007/978-981-13-0761-4

Saaty, T. L. 1999. Fundamentals of the analytic network process. Proceedings of the ISAHP 1999, 1-14. https://doi.org/10.1007/s11518-006-0158-y

Saaty, T. L., \& Vargas, L. G. 2006. Decision Making with the Analytic Network Process: Economic, Political, Social and Technological Applications with Benefits, Opportunities, Costs and Risks (Second). https://doi.org/10.1007/978-1-4614-7279-7

Mohamadghasemi, A., Hadi-Vencheh, A., Lotfi,F. H., \& Khalilzadeh, M. 2020. An integrated group FWAELECTRE III approach based on interval type-2 fuzzy sets for solving the MCDM problems using limit distance mean. Complex \& Intelligent Systems, 6(2), 355-389. https://doi.org/10.1007/s40747-02000130-x

Mohamadghasemi, A, Hadi-Vencheh, A., \& Hosseinzadeh Lotfi, F. 2020. The multiobjective stochastic CRITIC-TOPSIS approach for solving the shipboard crane selection problem. International Journal of Intelligent Systems, 35(10), 1570-1598. https://doi.org/10.1002/int.22265

Mohamadabadi, H. S., Tichkowsky, G., \& Kumar, A. 2009. Development of a multi-criteria assessment model for ranking of renewable and non-renewable transportation fuel vehicles. Energy, 34(1), 112-125. https://doi.org/10.1016/j.energy.2008.09.004

Sakthivel, G., Ilangkumaran, M., Nagarajan, G., Raja, A., Ragunadhan, P. M., \& Prakash, J. 2013. A hybrid MCDM approach for evaluating an automobile purchase model. International Journal of Information and Decision Sciences, 5(1), 50-85. https://doi.org/10.1504/IJIDS.2013.052017

Shariff, A., Aminuddin, A., Muhammad, K., \& Khalif, K. 2019. Fuzzy Analytic Hierarchy Process using Intuitive Vectorial Centroid for Eco-friendly Car Selection. Journal of Physics: Conference Series PAPER. https://doi.org/10.1088/1742-6596/1366/1/012076

Singh, J., Singh, H., \& Sandhu, A. S. 2018. Gearless Scooter Selection Using Multi-Criteria Decision Making. IUP Journal of Operations Management, 17(3), 21-41. 
Sri Yogi, K. 2018. Evaluation of purchase intention of customers in two wheeler automobile segment: AHP and TOPSIS. IOP Conference Series: Materials Science and Engineering, 330(1). https://doi.org/10.1088/1757$899 \mathrm{X} / 330 / 1 / 012065$

Sultana, U., Khairuddin, A. B., Rasheed, N., Qazi, S. H., \& Mokhtar, A. S. (2018). Allocation of distributed generation and battery switching stations for electric vehicle using whale optimiser algorithm. Journal of Engineering Research, 6(3), 70-93.

Tampatty, E. R., Kindangen, P., \& Tumbuan, J. . A. W. 2017. ANALYTICAL HIERARCHY PROCESS APPROACH ON CONSUMER PREFERENCE IN CHOOSING LOW COST GREEN CAR (LCGC) (CASE STUDY: TOYOTA AGYA, DAIHATSU AYLA, AND DATSUN GO+). Jurnal EMBA, 5(3), 4155-4164.

Wan, S. ping, Xu, G. li, \& Dong, J. ying. 2017. Supplier selection using ANP and ELECTRE II in interval 2tuple linguistic environment. Information Sciences, 385-386, 19-38. https://doi.org/10.1016/j.ins.2016.12.032

Yayla, A, Y., \& Yildiz, A. 2013. Fuzzy Analitic Network Process Based Multi Criteria Decision Making. South African Journal of Industrial Engineering, 24(2), 167-180.

Yim, K., \& Chong, M. 2018. A Study on the Purchase Intention of Eco-Friendly Vehicles by Korean and Japanese. International Journal of Pure and Applied Mathematics, 120(6), 5875-5901.

Yıldız, A., \& Ergül, E. U. 2014. Usage of Fuzzy Multi-criteria Decision Making Method to Solve the Automobile Selection Problem. The Journal of Engineering and Fundamentals, 1(1), 1-10. https://doi.org/10.17530/jef.14.01.1.1

Yousefi, A., \& Hadi-Vencheh, A. 2010. An integrated group decision making model and its evaluation by DEA for automobile industry. Expert Systems with Applications, 37(12), 8543-8556.

https://doi.org/10.1016/j.eswa.2010.05.021 